COMO CITAR ESTE ARTÍCULO:

Gamarra-Amaya, L.C. (2019). Damages and awards: a comparative study between Colombia and the United States. Revista Jurídicas, 16 (1), 139-152 DOI: 10.17151/jurid.2019.16.1.9.

Recibido el 7 de junio de 2017

Aprobado el 20 de junio de 2018

\section{Damages and awards: a comparative study between Colombia and the United States}

\author{
Laura Cecilia Gamarra-Amaya*
}

\section{ABSTRACT}

Since the inception of the theory of extra contractual liability, Colombia has strived to attain a system that fairly compensates the victims of illegal damage while keeping compensation proportional and equitable for all parties. The United States, by contrast, has developed a doctrine on damages that looks to reestablish the plaintiff's rights while issuing civil punishment to the offending party. This paper aims to make an approximation between two systems, giving special importance to new jurisprudence that points to the eventual recognition of punitive damages in Colombia and outlining the legal discrepancies that prevent punitive damages from becoming a reality in this South American country.

KeY WORDs: civil liability, damages, tort, extra contractual responsibility, punitive damages.
PLL.M International of Legal Studies (Georgetown University). Universidad Católica de Colombia, Bogotá, Colombia. E-mail: Icgamarra@ucatolica.edu.co.

Google Scholar. ORCID: 0000-0002-0823-6224. 


\section{Daños y premios: un estudio comparativo entre Colombia y los Estados Unidos}

\section{RESUMEN}

Desde el inicio de la teoría de la responsabilidad extracontractual, Colombia se ha esforzado por lograr un sistema que compense justamente a las víctimas de daños ilegales mientras mantiene la compensación proporcional y equitativa para todas las partes. Los Estados Unidos, por el contrario, han desarrollado una doctrina sobre daños que busca restablecer los derechos del demandante al tiempo que impone un castigo civil a la parte ofensora. Este documento pretende hacer una aproximación entre dos sistemas, dando especial importancia a la nueva jurisprudencia que apunta al eventual reconocimiento de daños punitivos en Colombia y destacando las discrepancias legales que impiden que los daños punitivos se conviertan en una realidad en este país sudamericano.

Palabras clave: responsabilidad civil, daños, responsabilidad civil extracontractual, daños punitivos. 


\section{Introduction}

One of the maxims of tort liability says: "All damage must be repaired." This has remained a central structure in the in the countries that are part of the legal family of Civil Law. Notwithstanding this inclination, the content and scope of such liability have been subject to change in recent legislation inspired by countries in the AngloSaxon tradition of common law in order to sanction and prevent harmful behavior.

Throughout Europe, North and South America, there have been systems designed to repair the victim of illegal conduct, either in his or her personal integrity or property, when this illegal conduct is the responsibility of another party. The United States, as did other common law countries, took its inspiration in tort law from the common law of England. In contrast, the law of reparations in Colombia and other South American countries takes roots in the Civil Law system which codifies all legal precepts.

In Colombia, as in most systems, civil liability is an essential institution of the law of damages, and it covers two singular areas that have, independently, their own legal system. These are contractual and extra contractual responsibility, which, as their names suggest, occur within different frameworks. Thus, the majority doctrine in the South American country understands that all damages arising under a contractual relationship should be considered part of the contractual liability, thus leaving the remainder in the non-contractual field.

Colombia largely adheres to two types of theories regarding legal pluralism: the first type, independent from government institutions and reflected in the constitutional text, includes mechanisms of alternative dispute resolution like conciliation or indigenous jurisdictions. The second type of legal pluralism has a completely extrajudicial sphere of application and is parallel to official legal practices, such as those exercised by local organizations or armed groups that regulate conflicts in the absence of government institutions (Llano, 2016).

The present article aims to examine Colombian regulations relating to illegal damage, or daño antijurídico, through a comparative analysis of United States tort law. In the course of the article, distinctions, variations and critiques of the system will be provided, and recommendations will be issued.

\section{Damages in Colombia}

Article 90 of the Colombian Constitution orders the State to be legally responsible for all tortious acts attributable to its own wrongdoing (Constitución Política, 1991). Illegal damages have been defined as those caused by the action or omission of public authorities, suffered by a person who should not suffer it (Consejo de Estado). 
Classic theories of damages under the Colombian legal system define them as "Patrimonial aminoration suffered by the victim" (Henao, 1998). Therefore, under this definition, there are three clear elements of damages, as follows:

a. Damages have to be certain: The claimant must have suffered a real and true injury (SC 16690-2016, 2016).

b. Damages have to be personal: The person or people claiming the loss due to the damage must have standing. In regards to this, the Colombian Civil Code, in its article 2342 establishes that:

Compensation may be claimed not only by the owner or possessor of the property on which the damage has occurred, but also the usufructuary, the inhabitant, or the user, if the damage is prejudicial to the usufruct, habitation or use. (Colombian Civil Code, 2000)

c. The interest affected must be legal: The damage must affect a vested interest, legally protected by the Colombian Constitution and laws (Acevedo, 2004).

Colombian damages have also been classified depending on the interest that has been affected. Therefore, we have monetary (material, patrimonial) damages and non-monetary (extra-patrimonial) damages.

\section{Monetary damages}

Monetary damages are material compensation that seeks to repay the victim of wrongdoing. In this case, the party responsible for the damages, utilizes monetary means to make the injured party "whole" again. This type of compensation is used when the injury directly affects the victim's estate and his or her situation is now different from what it used to be before the event that caused the damage.

Articles 1613 and 1614 of the Colombian Civil Code classify monetary damages awarded to the injured party in two categories: Daño emergente and Lucro cesante. Article 1614 states that daño emergente arises out of "the damage or loss that arises of an obligation that was not fulfilled, of erroneous fulfillment, or fulfilled late". It refers to the losses arising as a result of the damage and to the injured party's diminished estate as a result of the harmful conduct. Lucro cesante, by contrast, refers to the loss of earnings suffered as a result of the damage. Thus, what in normal circumstances should have resulted in a pecuniary advantage to the victim did not occur, nor will it occur. Because of that, the expectation of future economic benefit disappears with the damaging event.

In regards to the calculation and quantification of this type of damage, the Colombian Supreme Court has established that "Not only can they be assessed 
by legal means, but they can also be quantified. "Arbitrum judicum", or the discretion of the judge to quantify the amount of damages, does not apply in this case, and it is the plaintiff's burden to show legal proof of monetary damages (Pineda, 2015).

\section{Non-monetary damages}

Non-monetary damages are defined as the ones resulting from the injury to interests that do not have an economic component, being non-negotiable and lacking monetary value. In this regard, Colombian legal doctrine has been evolving over the last 80 years, since the controversy about the difficulty of compensating this kind of damage had previously generated the idea that it was impossible to return things to the state they were in previous to the occurrence of the damage (Pineda, 2015).

In this type of damages, the money received by the victim does not seek to subrogate the monetary loss suffered by the victim, but instead seeks to compensate the victim.

These damages, also called immaterial, affect the deepest spheres of a person's life. The social sphere, product of interpersonal relationships which consists of honor, reputation, credit, etc., and an affective sphere, which consists of our intimate affections, our convictions and beliefs, our feelings; and everything that touches our individual psyche (Represas, 2006).

Colombian legislation has seemed to lag behind doctrinal development in this matter. However, three types of non-monetary damages have been clearly expressed in the Colombian legal system.

i. Moral damages affect the intimate or inner sphere of the person,

Resulting in feelings of desolation, anguish, sadness, bitterness, etc., they are the damages suffered by the person arising from a tortious act and that offends the moral personality of the victim. These types of damages are of a subjective nature, because it is understood that the victim's losses cannot be replaced by monetary means. Examples of moral damages are the loss of life, physical and moral integrity, mental health, honor, dignity, etc.

In Colombia, moral damages were recognized for the first time on July 21, 1922, by the Supreme Court of Justice, whose Magistrate Speaker was Dr. Tancredo Nannetti; In this case the court awarded the sum of $\$ 3,000$ pesos to the plaintiff because of the tortious conduct of the 
employees of the Municipality of Bogota, who abducted the remains of his deceased wife. (Caso Villaveces, 1922)

The quantification of moral damages is particularly difficult, as it is impossible to exactly establish which, if any amount, would suffice to lessen the victim's pain and suffering. The Colombian Supreme Court, on September 30, 2016 said:

Because the pain experienced and the lost affections are irreplaceable and their compensation is priceless, it remains in the judge's discretion to give, at least, a measure of compensation or satisfaction, normally estimable in money, according to criteria of reasonability and in accordance with the actual circumstances in which the event that gave rise to suffering took place (Caso Pulgarín, 2016).

This sentence is probably one of newest and most forward thinking pieces of jurisprudence regarding damages, and will be subject to further analysis.

ii. Damages to relationships affect a person's external sphere, when the tortious act has the consequence of impairing the victim's quality of life, in the loss or difficulty of establishing contact or relating to people and things, in order to enjoy an ordinary existence, as well as the inability of the affected person to deploy the most basic behaviors in daily life. It can be said that a person suffering from damage to relationships must face an existence in conditions more complicated or demanding than the others, as he or she must face abnormal circumstances and barriers, in which even the simplest can become difficult.

A person's ability to enjoy their existence to flourish in a supportive environment and build lasting relationships that will add to the enjoyment of life is cut off by the tortious act, creating a permanent detriment that will be carried by the victim for a long time.

The Colombian Supreme Court, said on April 4, 1968, when referring to personal damages:

It is the impairment to physical or mental integrity, or in injury to the honor, liberty or intimacy... such damage can give rise to multiple significant consequences, some of them with patrimonial character like, for example, "the costs of healing or rehabilitation" or "lost earnings", while others of a different nature can affect the "sentimental balance", or be evidenced in "breakdowns, either permanent or 
temporary, in the person's life and relationships. (Responsabilidad Civil del Transportador de Personas, 1968)

As far as compensation is concerned, legal systems of Roman-Germanic origin, including Colombia, have traditionally considered that, regarding tortious acts, reparations should seek to leave the victim in the situation in which they were before the occurrence of the event, but in no case should it imply a pecuniary increase that does not correspond strictly to the injury (García-Matamoros, 2010). In the words of the Colombian Constitutional Court: "compensation for damages must correspond directly to the magnitude of the damage caused, but it cannot exceed that limit". The explanation given for this rule is based on a general principle of law: "If the damage is compensated above the actual amount, there is enrichment without just cause for the victim. Thus, the damage is the measure of compensation" (Henao, 1998).

\section{Damages in the American legal system}

In the United States, the law of damages constitutes one of the main elements of the legal system. It is universally recognized, because of its complexity, dynamism and growing influence on the international scene.

The concept of damages under American law has remained fairly stable despite differences in State law. Damages are imposed as a remedy or compensation in favor of a party whose interests have been violated due to a tortious act. Therefore, damages are understood as the consequence, not the injury itself, like the Spanish word daño implies.

Understanding damages as the consequence, not the cause of loss does not mean that the actual harm or injuries aren't an essential part of the development of tort law. Courts consider the type of injury in order to award damages proportional to the plaintiff's loss.

In the United States, courts award damages to compensate the wrongdoing committed by the defendant against the plaintiff (Birdsall v. Coolidge, 1876). Defendants are "only entitled to recover those damages which were actually caused by the defendant's conduct which breached his contract and/or violated his constitutional right to due process" (Alston v. King, 2000). As in Colombia, the main goal of the judge in awarding damages is to make the plaintiff whole, in the position that it was before the harmful conduct. Damages are divided into different categories based on the type of recovery (U.S. Legal):

1. Compensatory damages: They are awardable to a person as compensation, indemnity or restitution from harm or loss caused by the tortious act of 
another (Restatement (Second) of Torts). It provides a plaintiff with the necessary amount to replace a loss but nothing else. Just like in Colombian law, these damages are easy and fairly straightforward to calculate given the nature of the loss.

2. Future damages: This type of damages aims to compensate the plaintiff only when there is a reasonable expectation of a loss or injury in the future because of a negligent or malicious act or omission of a defendant. A satisfactory basis for future damages is required for its award.

3. Incidental damages: They are awarded to a plaintiff when certain expenses that are incidental to the loss or damage. The expenses should be incidental to the loss and should be reasonable.

4. Nominal damages are awarded to an individual in an action when the individual suffers injury or loss that is to be compensated, but cannot offer proof of a loss. An example of this is when a plaintiff argues that a defendant's conduct caused physical harm but fails to produce medical records or any relevant evidence. In this case, plaintiff's is awarded a small, nominal sum. Nominal damages are also awarded when the nature and extent of the injury is minimum (The Free Dictionary).

5. Temperate damages or moderate damages are more than nominal damages. For awarding temperate damages, courts should be convinced that there was a breach of legal duty by the defendant, but when the loss suffered by the plaintiff cannot be deduced with clarity (U.S. Legal).

6. Punitive damages: This category of damages is awarded against a wrongdoer for his/her negligent, malicious act, or omission that causes grievous damage to another. It also acts as a deterrent or punishment, so that others don't commit the same tortious act. The judge or jury, depending on the local laws, has discretion to award of punitive based on the extent of plaintiff's injury and the wrong-doer's behavior. In Smith v. Wade, the Supreme Court held that Section 1983 of the United States Code authorizes the award of punitive damages against state or local officials in their individual capacity (Smith v. Wade, 1983). Although the courts maintain that damages may be awarded upon showing of malicious or egregious conduct, such conduct or behavior is not necessary to award punitive damages to the plaintiff. The determination of whether to award punitive damages once a showing of malicious or recklessly indifferent conduct is made rests within the discretion of the jury or judge (Fairley v. Jones, 1987). 
Courts repeatedly have upheld punitive damage awards against public officials for discriminatory employment practices, police brutality, and unlawful searches and seizures. Courts have also upheld awards for prisoner mistreatment, including deliberate indifference to medical needs, violations of the right to procedural due process, and violations of First Amendment rights. Punitive damages may be awarded even when the plaintiff suffers only nominal damages from a deprivation of federal rights. However, if a punitive damage award is "grossly excessive" in relationship to the state's legitimate interest in punishing and deterring unlawful conduct, it runs afoul of substantive due process and may be reduced or reversed on appeal. (Shriver Center)

Punitive damages are non-compensatory, and their nature seeks to punish the defendant and deter future wrongdoing, rather than make the plaintiff whole (BMW of North America, Inc. v. Gore, 1996). In order to award punitive damages, the judge or jury must determine that the defendant had the intent to cause harm to the plaintiff. This intent must go beyond mere negligence, as aggravating circumstances such as malice and bad faith must be demonstrated (Burton's Legal Thesaurus).

Some consider that these subjective elements do not have to be so transcendental and adopt a less strict position (Garcia-Matamoros, 2010). In this context, the concept of punitive damages cannot be applied without creating a climate of legal insecurity, in which almost any defendant would be subject to punitive damages for almost any tort, rendering its deterring purpose as useless.

Proponents of punitive damages believe that deterrence is their most important function.

\begin{abstract}
Because the law does not catch and punish all persons who wantonly violate the rights of others, supporters argue that punitive damages help deter misconduct by publicizing, and at times sensationalizing, the punishment of those persons found guilty of egregious misconduct. Punitive damages tell manufacturers and other businesses that financial penalties will follow if companies sell products known to be defective. (West's Encyclopedia of American Law, edition 2, 2008)
\end{abstract}

Punitive damages also serve the important function of reestablishing the emotional wellbeing of the plaintiff, since intangible harm cannot be calculated using the parameters of compensatory damage.

Critics of punitive damages argue that these large monetary awards are "unfair, unreasonable and not productive for society" (West's Encyclopedia of American Law, ed. 2, 2008). They believe that these criminal fines should be managed by criminal, not civil justice. In addition, critics of punitive damage argue that the standards for determining the defendant's liability are vague and confusing for juries, who 
eventually end up awarding a large quantity without much regard for the actual circumstances of the event, making it easier for plaintiff's attorneys to "venue shop" for a jurisdiction with friendly juries. Many states have now developed guidelines to instruct juries in the award of punitive damages.

\section{New developments in Colombian jurisprudence}

Traditionally, Courts have held that "(regarding) State liability, the imputation is not identified with material causality, since the attribution of liability can also be due to normative or legal criteria. Once the State's obligation has been defined, the agency to which the damages are attributed must be determined, that is, the attribution factor is defined (failure in service, risk created, equal protection). Attributing the damage caused by an agent to the State service means that the agent is responsible for its repair, but this attribution is only possible when the damage has had a link with the service. That is, the actions of officials only compromise the assets of public entities when they have some connection or link with to public service" (Sentencia de 16 de septiembre de 1999, Exp. 10922, 1999). This means that the State is liable for reparations to illegal damage when the person who suffers it has no legal duty to stand it. Once the damage has been verified, and the agency responsible for the damages has been determined, the State must fully indemnify, in order to make effective the principle of equal protection. The Courts have also said in the past that this indemnification must be proportional to the damage suffered (Sentencia de 16 de septiembre de 1999, Exp. 10922, 1999).

The proportionality of the indemnification and damage renders an interesting complication, as Colombia has previously introduced the theory of civil liability for dangerous activities, codified by article 2356 of the Civil Code, which reads: "As a general rule all harm resulting from the malice of negligence of another person must be compensated by the obligator. Particularly obligated to reparation are:

1) He who imprudently fires a firearm;

2) He that removes things from a pipe or sewer line, or leaves them open in a street or highway, without the precautions needed to prevent the injury (falling) of its transients either day or night;

3) He who does construction or reparations to aqueducts or fountains that cross roads that it has it in a state that could cause harm to those traveling the roads.

This article places the burden of proof on the defendant to show that he was not engaging in this type of conduct, exonerating the plaintiff from liability in the cases where the defendant was engaging in these dangerous activities. Further, article 2357 of the Civil Code contemplates the adjustment of damages by the defendant if the plaintiff behaved in an imprudent manner. 
For the effective application of article 2356 and the natural consequence explained in article 2357, there needs to be malice or negligence on the part of the responsible party. This requirement is founded on the notion of fault. The fact that fault is presumed or proved is a matter of legal interpretation. The Supreme Court has debated over the elements required to equate an activity to a dangerous one. The modern trend is to hold he who has the "intellectual direction and control over the dangerous activity (Bartels, 2001).

Despite this apparent conflict, Colombian jurisprudence continues its approximation towards a novel type of damages. Sentence SC10297-2014 granted that since every individual has a wide variety of legal rights, and the injury to each one of them gives rise to separate compensation. Damaging events can lead to the affectation of several of these rights, with the victim entitled to be compensated for each damaged property (Sentencia SC-10297-2014, 2014).

In a recent sentence, the Supreme Court launched what seems like a new development in the doctrine of damages in Colombia (Sentencia SC13925-2016, 2016). In an innovative approach to what has been decided in the past, a new theory seems to emerge with marked Anglo Saxon undertones, the Court has expressed:

It is then perfectly permissible and necessary to repair the damages caused to the higher goods, in which case the injurious consequence (violation of the legal right) cannot be confused with the reprehensible conduct (whose demerit does not consist in the mere injury of the protected good but in the violation of the objective duty of prudence owed to avoid producing damages). There is, therefore, no reason to exclude compensation of damages resulting from this type of tort, otherwise the court would be left with a reductionist vision for which only economic or patrimonial repercussions would be worthy of compensation, leaving the higher goods unprotected. (Caso Pulgarín, 2016)

In this context, "higher goods" refer to life, honor, personal integrity, privacy and good name. These are all part of the personal sphere that has no calculable monetary value. The Court, in this sentence, goes as far as to say that no legislative action is necessary for the award of monetary damages when these higher goods are violated, as

Unlike the classical liberal conception of constitutionalism, according to which general principles were not amenable to immediate application since they demanded interpretation and concretization by the legislator, in contemporary neo-constitutionalism general principles and program norms can produce direct effects and be applied by any judge in the event of any dispute. (Caso Pulgarín, 2016) 
The first revelation of this opinion is that the Court is recognizing the lag between the legislator's work and the realities of life. The judge then decides that in the absence of legislation, it is up to the Court to define the new parameters for the consideration of damages that do not have a monetary value. Further, when discussing the element of causality between the tortious conduct and damages, the Court opens a door by establishing that omission, as well as action can cause the payment of damages.

Therefore, the conduct to which the injurious consequence is attributed assumes the meaning of a legally relevant fact attributable to an agent who had a duty to act in accordance with the function assigned by the law (imputatio facti), but says nothing about how that action or omission should have been (imputatio iuris), nor about what is the legal consequence that must be imposed by virtue of the finding of the factual assumption foreseen in the standard (applicatio legis). (Caso Pulgarín, 2016)

It is important to remember that despite this leap in legal development, Colombia does not yet recognize the idea of punitive damages. As discussed in a previous section, punitive damages are those awarded to an injured party that go beyond that which is necessary to compensate the individual for losses and is intended to punish the wrongdoer (Black, 1990).

At first glance, Sentencia SC13925-2016 seems to shine a light in the path to fully recognizing punitive damages in Colombia. However, the differences in the origins of legal doctrine, as well as cultural differences make this a difficult process. In Colombia, the elements of intent and malice are subject to criminal prosecution in most cases, and belong to the sphere of criminal law. It's as if the legislator decided that the best way to punish those responsible for the vilest of tortious acts, is by depriving them of their freedom, versus civil economic consequences.

This sentence has created chaos amongst legal scholars, as it has opened a door that the legislator has kept closed in the past. In some cases, it has been referred to as the big bang sentence (Quiñones, 2017) because of the potential repercussions it carries. "The constitutional precepts that protect particular legal rights are not (...) just principles that contain optimization mandates that must be fulfilled when possible (Caso Pulgarín, 2016). "By saying this, the Court is broadening the spectrum of protection to these "higher goods" even when this protection is not factually or legally possible. To this effect, Javier Tamayo Jaramillo, former Supreme Court Magistrate, explains that any constitutional right, fundamental or not, is only enforceable if it is factual and legally possible. For example, if the doctor causes harm to the patient, due to an unforeseen cause, the victim has no claim against the doctor or State as the damage is not unconstitutional and the right is not enforceable (Quiñones, 2017). 


\section{Conclusion}

Non-contractual civil liability under Colombian law, especially the law of damages, is under constant evolution. However, the basis for punitive damages, concretely, the kind of damages that is awarded when the victim has suffered due not only to the negligence, but due to the intentional conduct of the defendant, is not well cemented in Colombian codified law. Article 28 of the Constitution establishes the principle of legality; that is, the universally recognized principle of that there is no crime without previous legislation, and as it has been shown in this paper, current Colombian law does not contemplate the calculation of punitive damages as a civil punishment.

The Courts have dealt with this struggle and have attempted to better equip the legal system with tools designed to handle the changing outlook and modernize the way the law is created. However, this is a long struggle against decades of doctrine equating punitive damages to illegal enrichment, and recent efforts in common law jurisdictions, like the United States, to cap the amounts of punitive damages awarded to plaintiffs (BMW of North America, Inc. v. Gore, 1996). Colombian negligence laws use criminal principles to apply what should always be civil consequences. This duality has brought on confusion and discord amongst both legislators and scholars, who have tried to untangle this morass for decades. Notwithstanding, recent jurisprudence seems to point in the direction of creating a balance between the plaintiff and the injuring party, even as American Courts -in some states and jurisdictions- try to limit the amounts victims can receive.

\section{Bibliography}

Acevedo, J.R. (2004). Fundamentos de la responsabilidad extracontractual de la administración pública. Bogotá: Leyer.

Alston v. King, 231 F.3d 383 (7th Cir. Ind. 2000).

Bartels, N. (2001). A Comparative Analysis of United States and Colombian Tort Law: Duty, Breach, and Damages. 13 Pace Int'l L. Rev. 59.

Birdsall v. Coolidge, 93 U.S. 64 (U.S. Supreme Court 1876).

Black, H.C. (1990). Black's Law Dictionary. 6th Edition. St. Paul: West Publishing Co.

BMW of North America, Inc. v. Gore, 517 U.S. 559 (1996).

Burton's Legal Thesaurus. (n.d.). Burton's Legal Thesaurus, 4E. S.v. "punitive damages. Retrieved from http://legal-dictionary.thefreedictionary.com/punitive+damage

Caso Pulgarín, SC13925-2016 (Corte Suprema de Justicia Abril 2016).

Caso Villaveces (Corte Suprema de Justicia July 21, 1922).

Colombian Civil Code. (2000). Colombian Civil Code. Bogotá: Ecoe Ediciones.

Congress of Colombia. (1998, July 8). Law 446 of 1998. "Por la cual se adoptan como legislación permanente algunas normas del Decreto 2651 de 1991, se modifican algunas del Código de Procedimiento Civil, se derogan otras de la Ley 23 de 1991 y del Decreto 2279 de 1989, se modifican y expide. Bogotá, Colombia: Official Diary. 
Consejo de Estado. (n.d.). Sentencia SCA-SEC3-22298. Retrieved from http://lexbasecolombia.net. jurisprudencia/consejo: http://lexbasecolombia.net.jurisprudencia/consejo

Constitución Política. (1991). Constitución Política de Colombia. Retrieved from http://www. corteconstitucional.gov.co/inicio/Constitucion\%20politica\%20de\%20Colombia\%20-\%202015. pdf

Corte Suprema de Justicia. Sentencia SC10297 de 2014. Magistrado Ponente: Ariel Salazar Ramírez.

Fairley v. Jones, 824 F.2d 440 (5th Circuit 1987).

García-Matamoros, L. (2010). El concepto de los daños punitivos o punitive damages. Estudios SocioJuridicos ,5(1), 211-229

Henao, J.C. (1998). El daño: analisis comparativo de la responsabilidad extracontractual del Estado en derecho colombiano y francés. Bogotá: Universidad Externado de Colombia.

Llano, J.V. (2016). Pluralismo Jurídico, Diversidad Cultural, Identidades, Globalización y Multiculturalismo: Perspectiva desde la Ciencia Jurídica. Novum Jus, 49-92.

Pineda, J.A. (2015). Una Experiencia Comparada de Derecho de Daños: Colombia y Estados Unidos (A Comparative Experience of Torts Law: Colombia and the United States). Práctica de Derecho de Daños, No 122, Primer trimestre de 2015. Retrieved from https://ssrn.com/abstract=2590713

Quiñones, S.R. (2017, February 23). Ámbito Jurídico. Retrieved from Sergio Rojas Quiñónez. "Hacia una nueva responsabilidad civil?". Ámbito Jurídico: https://www.ambitojuridico.com/ BancoConocimiento/Civil-y-Familia/hacia-una-nueva-responsabilidad-civil

Represas, M.L. (2006). Tratado de la Responsabilidad Civil. Tomo V. Cuantificación del daño. Buenos Aires: Moron.

Responsabilidad Civil del Transportador de Personas (Corte Suprema de Justicia Abril 4, 1968).

Restatement (Second) of Torts. (n.d.). Restatement (Second) of Torts § 903.

Sentencia 5 de marzo de 1993 (Corte Suprema de Justicia 1993).

Sentencia SC 16690-2016 (Corte Suprema de Justicia 11 17, 2016).

Sentencia de 16 de septiembre de 1999, Exp. 10922, sentencia de 16 de septiembre de 1999, Exp. 10922 (Consejo de Estado September 1999).

Sentencia SC-10297-2014, SC-10297-2014 (Corte Suprema de Justicia 08 05, 2014).

Sentencia SC13925-2016, Sentencia SC13925-2016 (Corte Suprema de Justicia 2016).

Shriver Center. (n.d.). Federal Practice Manual for Legal Aid Attorneys. Retrieved from www. federalpracticemanual.org.

Smith V. Wade, 461 U.S. 30 (1983).

The Free Dictionary. (n.d.). http://legal-dictionary.thefreedictionary.com/damages. Retrieved from http:// legal-dictionary.thefreedictionary.com/damages

U.S. Legal. (n.d.). U.S. Legal. Retrieved from https://damages.uslegal.com/: https://damages.uslegal.com/

West's Encyclopedia of American Law, ed. 2. (2008). Punitive Damages. Retrieved from http://legaldictionary.thefreedictionary.com/punitive+damage 